RAINBOW Vol. 8(2)(2019)
UNNES Journal of Literature, Linguistics and Cultural Studies
$\underline{\text { http://iournal.unnes.ac.id/sju/index.php/rainbow }}$

\title{
The Dilemma of Being American as A Consequence of Ethnic Segregation in Toni Morrison's Beloved
}

\author{
Novia Sekar Ayuningtyas ${ }^{\bowtie}$, Mohammad Ikhwan Rosyidi \\ English Department, Faculty of Languages and Arts, Universitas Negeri Semarang, Indonesia
}

\begin{abstract}
Article Info
Article History:

Received 6 September

2019

Approved 26 November

2019

Published 29 November 2019

Keywords: American,

Deconstruction,

Dilemma, Ethnic

Segregation

Abstract

Slavery was a central institution in American society and was accepted as normal and applauded as a positive thing by many white Americans. America was full of Negro slaves when there were many injustice actions done by white to black Beloved is a novel written by Toni Morrison in 1987, explores the hardships endured by a former slave woman and her family during the slavery and the Reconstructions eras. This study aims to explain the dilemma experienced by the main character of being American and its correlation between the main character's dilemma and ethnic segregation by the White Americans against the Afro-Americans as portrayed in Beloved novel. The method used in this study is a qualitative study analyzed by deconstruction theory of Paul de Man. Meanwhile, the method of data analysis is based on the dilemma experienced by African-American in the novel and its correlation between the dilemma and ethnic segregation. Morrison's novel shows that the dilemma experienced by the main character in the novel is divided into the episodes of control, gender role, and humanity service. The correlation between the dilemma and ethnic segregation is portrayed through the struggle of Afro-American fight against the domination of White Americans. In conclusion, ethnic segregation in America creates dilemma for Afro-American and it should be removed to vanish any differentiation and live in harmony..
\end{abstract}

(C) 2019 Universitas Negeri Semarang 


\section{INTRODUCTION}

America is a diverse nation, popularly known as the nation of liberty. Since America is a diverse nation, it is constructed by various people from different races, religion, cultures, etc. Mostly people living in the United States come from various parts in the world, and they are mostly immigrant. For example is immigrants from Africa, often called as Negro or black. Due to the diversity, it cannot be separated from differentiation. Commonly, it comes between the differentiation of race, namely white and black. It also evokes the problem of slavery.

Slavery was a central institution in American society and was accepted as normal and applauded as a positive thing by many white Americans. America was full of Negro slaves when there were many injustice actions done by white to black.

Panda and Sethi (2017) say that insufficient or no food for days, lack of freedom and no funeral after death was attached to the fate of the slaves. The depiction of the life of slavery can be represented through literary works.

Literary works, exist to either talk or giving critique towards the society, especially about what experienced or what happen surrounds the author. Literary work, usually is a product of imitation developed by the author. One of literary works that represent the life of slavery in America is Beloved, a novel written by Toni Morrison in 1987, explores the hardships endured by a former slave woman and her family during the slavery and the Reconstructions eras. It centers on the powers of memory and history. If I look at American history, clearly in 1873 was when the civil war was over. But apparently, the oppressor by American to African-American will be unforgettable. On the other hand, the reconstructions also hinged on radical new ideas about "liberty" and "equality," which challenged slavery's long tradition of extreme human inequality. Beloved is a complex novel as AfricanAmerican literature that won many awards. This novel focuses on Morrison's representation of African-American experience and history. The phenomenon of differentiation becomes common problem that happens every time and everywhere in most part of the world. It should be fought against to achieve equality so that there would be no more differentiation.

There are two other novels similar to Beloved. First novel entitled Night John by Gary Paulsen and published in 1993. Second, novel entitled Roots: The Saga of an American Family by Alex Haley published in 1976. The similarity of these three novels is equally telling about the darkness of African-American slavery in America and also about the characters in the story who tried to escape from slavery and tried to get their freedom. In addition, there are many journals that dealing with Beloved by Toni Morrison analyzed with many approaches. First, the deconstruction theory. Second approach is feminism. Third approach is psychology. Fourth is postcolonial. The writer also find many related topics to the recent research such as topic about race, gender, motherhood, slavery, historicism, culture, ghost, and magic realism. However, the writer focuses on analyzing the difficulties of being American as rejection of differentiation in Toni Morrison's Beloved by using Deconstruction theory by Paul de Man, which seeks to deconstruct the privileged claims in Romanticism of symbol over allegory, and metaphor over metonymy. Before deconstructing the result, the writer uses structuralism approach to find the binary opposition. Structuralism is defined as a way of conceptualizing our experience in terms of polar opposites, which is called binary oppositions (Sahoo, 2014). When structuralism finds order and meaning in the text as in the sentence, deconstruction finds the contrary, it concerns in disorder and constant tendency of the language to refute its apparent sense: text are found to deconstruct themselves rather than to provide a stable identifiable meaning. (Guerin, 1999: 340). 
Based on the theoretical framework above, the research questions are what dilemma experienced y the main character in Beloved living as an Afro-American and its correlation against the ethnic segregation done between black and white Americans. The aim of this study is to describe the dilemma of being American and giving it the correlation to the ethnic segregation between black and white.

\section{METHODS}

This research is a qualitative-descriptive study which contains words, sentences, paragraphs to arrange and present the result. Since the data would be the cases of the dilemma of being American as a consequence of ethnic segregation and its correlation to the ethnic segregation between black and white, the writer would use some theories related to the topic. They are structuralism to find out the binary oppositions exist in the novel and deconstruction theory to analyze how they react towards the dilemma of being Afro-American as the consequence of ethnic segregation. The material object of this study is Toni Morrison's novel entitled Beloved which contains of two hundreds and ninety eight pages, written in 1987. Its formal object is the study of Morrison's novel concerning on binary opposition in novel, meaning, and relations in the novel which depicted the deconstruction showing the dilemma experienced by the main character against the ethnic segregation. The data analysis is taken by some procedures: (1) describing data in binary opposition (2) data is interpreted and related through deconstruction theory.

\section{RESULTS AND DISCUSSIONS}

The Dilemma Experienced by the Main Character of Being American in Toni Morrison's Beloved

Living in America is not as easy as it seems to be. There is a gap in America, especially towards differentiation, for example is race.
There is ethnic segregation between black and white that can be seen as clear as crystal. Black or Nigger refers to the African-American who have dark skin, while white for fair skin. This aspect can affect their whole living and creates some dilemma.

Dilemma is a situation in which a difficult choice has to be made among different things someone can do, sometimes the results are not the ones he wants, that makes it confusing. When someone experiences dilemma, it means that he/she have some possibilities to decide but he is confused which one he will choose.

In this case, the dilemma is experienced by the main character of the novel, namely Sethe. She comes from black society who live in America. Though America is known as salad bowl where many people from many countries gather become one society, in fact there is still segregation among them. Not all people are welcomed warmly, not all freedom people can get in their lives. The most obvious one is ethnic segregation between white society and black society. They live separatedly due to the differentiation., such as written on the excerpt below:

Odd clusters and strays of Negroes wandered the back roads and cowpaths from Schenectady to Jackson. Dazed but insistent, they searched each other out for word of a cousin, an aunt, a friend who once said, "Call on me. Anytime you get near Chicago, just call on me." Some of them were running from family that could not support them, some to family; some were running from dead crops, dead kin, life threats, and took-over land (Morrison, 1987: 73)

Due to the segregation, they live in difficulties, and the only way to escape is by running away from the control of white society. Afro-American or nigger are treated differently because they come from different ethnic or race. They have dark skin, while other Americans have fair skin. This condition makes their lives difficult and experiences some dilemma

\section{Episode of Control}


This episode describes the control as one of the dilemma experienced by the main character of being an Afro-American. Control here means the way they use their authority to rule the one who are submissive. The one who hold the control is white, while black should obey the rules and being controlled. In other words, the oppressive side is called as the colonizer, and the oppressed side is called as the colonized.

As white are superior over the blacks, they can do everything they want such as oppressing the submissive side. It makes the black society feel suppressed and unsafe, seen from the following quotation:

She just flew. Collected every bit of life she had made, all the parts of her that were precious and fine and beautiful, and carried, pushed, dragged them through the veil, out, away, over there where no one could hurt them. Over there. Outside this place, where they would be safe. (Morrison, 1987; 163).

From the quotation, we know that this difficulty makes their mind thinking about safe place out of suppression and hurt. The only way to escape is by leaving the previous life which is precious, fine, and beautiful to another better place where no one could hurt them and be safe from all colonization. This fact shows that racial difference has big impact to their lives. The white society act as a colonizer while the black society are colonized through the rules made by white. As a consequence, they are controlled by white's rules and regulations.

There is injustice experienced by black through the segregation created by white. The rules and regulations don't take sides with blacks. Therefore, they experience dilemma because they have no control. There is nothing they can do except obeying the rules of the whites. For example, black can only work as low level workers such as slaves. It happens because white have control to the economical condition and makes black lives in difficulty, proved by the excerpt below:

Then schoolteacher arrived to put things in order. But what he did broke three more Sweet Home men and punched the glittering iron out of Sethe's eyes, leaving two open wells that did not reflect firelight (Morrison, 1987; 9).

From the explanation above, it can be seen that white are powerful even to destroy the blacks' houses. Control makes them have power to do anything, while black is powerless to fight against white. They can only accept the injustice and do nothing to escape or run away.

Black is also treated inhumanely due to the ethnic segregation as if they are non human being, like in the quotation below:

No undreamable dreams about whether the headless, feetless torso hanging in the tree with a sign on it was her husband or Paul A; whether the bubbling-hot girls in the coloredschool fire set by patriots included her daughter; whether a gang of whites invaded her daughter's private parts, soiled her daughter's thighs and threw her daughter out of the wagon. (Morrison, 1987; 251).

The quotation above shows that white as the colonizer treat the black inhumanely such as killing and raping girls, a very cruel actions to do which shows injustice between white and black. Therefore, there is dilemma of control in the world of black and white in America.

\section{Episode of Gender Role}

Second binary opposition is about the dilemma of gender role experienced by the main character in Beloved novel. In this story, it is told that men hold the control over the women. It shows that men are powerful and women are powerless. Men as the head of family work outside the house, which means they have freedom. Meanwhile, women should stay inside the house because she is responsible for the house chore. It makes them feel restricted.

Men are powerful because they have roles to lead the family, make the rules, and decide things. They must work to live the life so that they can survive in the world of America where the economical condition don't take sides with black society. They live poorly with low-income. Therefore, men are supposed to be outside the house to work and do heavy jobs. Whereas, women are intended to stay inside the house. 
They have to do daily chores, have pregnant, and take care of the children, seen from the following passage:

Halle's woman pregnant every year including the year she sat by the fire telling him she was going to run. Her three children she had already packed into a wagonload of others in a caravan of Negroes crossing the river. They were to be left with Halle's mother near Cincinnati. Even in that tiny shack, leaning so close to the fire you could smell the heat in her dress, her eyes did not pick up a flicker of light (Morrison, 1987: 30)

The passage above shows that pregnancy is one of the obligation of a woman should do as wife. They have to take care of babies all day long. Men know little about things like that. (Morrison, 1987; 16). Besides, women also have to serve the husband when he is at home. They do not have right to work outside the house which make them restricted. As a result, women are seen as powerless because they do not have freedom to stand for themselves as independent gender. They also have to obey everything told or ordered by their husband because men are intended to be a leader. It is described through the following excerpt:

The restraint they had exercised possible only because they were Sweet Home menthe ones Mr. Garner bragged about while other farmers shook their heads in warning at the phrase.

"Y'all got boys," he told them. "Young boys, old boys, picky boys, stroppin boys. Now at Sweet Home, my niggers is men everyone of em. Bought em thataway, raised em thataway. Men everyone." (Morrison, 1998: 10)

From the quotation above, it is clearly told that They are proud to have more boys than girls, which means that there is a gender discrimination in accepting the presence of human based on gender. Therefore, women are usually silent. They have to obey what are ordered by men. They cannot refuse or reject anything, seen from the following quotation:

"I don't know where I'll be. Mr. Garnerthat's him what brought

me here-he say he arrange something for me." And then, "I'm free, you know." (Morrison, 1998; 143).

The quotation above explains that men are powerful, while women are powerless to the man's rule. Even when men are touching female's breast when they help them, women can do nothing about it (Morrison, 1987; 17). Woman can do nothing when man treats her badly, she just can keep silent and accept the bad treatment though she wants to cry. It proves that gender role also has caused dilemma of how they live in American's society as Afro-American because women feel more repressed of the way men treat them just because men have more power.

In terms of interaction, men are the ones who should talk and decide, while women are restricted to express their opinion publicly (Morrison, 1987; 188). They should pay attention to the way they behave in society live, such as what to speak or not, what good to wear and which one is proper rather than the other.

It can be summarized that gender role creates dilemma for the main character in living as an American because men are dominant while women are submissive.

\section{Episode of Humanity Service}

Humanity service here means the treatment or feedback between white and black in using or getting public service. Though there are many facilities and services available in America, there is still differentiation and uneven treatment got by black. They cannot have same service as white do. It shows that humanity service is differed due to the ethnic segregation.

It makes the black society have dilemma in surviving for their life. When white are sick, they can get hospital facility and accompanied by the doctors (Morrison, 1987; 194). It is because they have money and power so that they can get proper service. Also, when someone from their race is dead, they have funeral place and formal ceremony. It is different from black who get improper and poor humanity service, stated in the passage below: 
Baby Suggs didn't even raise her head. From her sickbed she heard them go but that wasn't the reason she lay still. It was a wonder to her that her grandsons had taken so long to realize that every house wasn't like the one on Bluestone Road. (Morrison, 1987; 3).

The statement above shows the condition of one of black who get sick and need treatment, but she could not get it because ahe didn't live at Bluestone road, where white rich society live. She can only be treated at home by her family. Even when there is someone died, they cannot have funeral place, seen from the following statement:

Sethe had no instructions except "Take her to the Clearing," which he tried to do, but was prevented by some rule the whites had invented about where the dead should rest. (Morrison, 1987; 171).

The statement above clearly describes that black is prevented by the white rules which says that black have different place about where the dead should rest, not a funeral. They are just buried near their house because they cannot afford the funeral fee, seen from the passage below:

"Filed a claim and rode on off. They going to let you out for the burial," she said,

"not the funeral, just the burial," and they did. The sheriff came with me and looked away when I fed Denver in the wagon. (Morrison, 1983; 183).

The statement shows that black could only get burial, not a funeral like what while people get when there is one of them died.

It can be concluded that humanity service is one of the dilemma experienced by the main character because of the ethnic segregation between white and black.

\section{The Correlation between the Main Character's Dilemma and Ethnic Segregation by White Americans against Afro-American}

Ethnic segregation between white and black do happens in society lives. There are many differentiation experienced by the main character in surviving the life of being an American who comes from black society.

\section{The Construction of Black Society}

Commonly, black society are low-class workers. They work for white as the rulers in the society. They are the ones who are being ruled and submissive to the dominance of white society. this condition is paradoxal to the saying that America as 'salad bowl', while anyone from various countries can be accepted warmly and treated same.

In fact, the difference between the races never end. Due to the differences, black society experience some difficulties in living the life. They feel the misery and poverty because white have taken their rights as human being, presented in following passage:

"Those white things have taken all I had or dreamed," she said, "and broke my heartstrings too. There is no bad luck in the world but whitefolks." 124 shut down and put up with the venom of its ghost. No more lamp all night long, or neighbors dropping by. No low conversations after supper. No watched barefoot children playing in the shoes of strangers (Morrison, 1987: 110).

From the excerpt above, it explains that black society hate white because they take and destroy their dreams as well. There will be no more happiness and peace in their life. They are often rejected just because they have different skin color.

\section{The Consequence of Ethnic Segregation between Afro-Americans and White Americans}

Ethnic segregation creates dilemma for the black society lives which are divided into three major issues as stated above, namely control, gender role, and humanity service. They have to deal with the consequences to survive in the world of America since segregation is an unfinished fight that will always happen. The only way to fight against the domination of white is by speaking up. If they are brave, they can do whatever they can, even make white as inferior against the strength of black.

The first struggle they have to face is control. White as the dominant ethnic has more control over the black ethnic. They create gap to 
segregate the skin color they have. White feel more free to dominate because they have everything while black do not have anything.

On the other hand, black actually can raise against white colonization, they also have control like what white do. It happens to those who reject ethnic segregation made by white, because they think that human is equal though they have different skin color. It is seen when black can kill white (Morrison, 1987; 265). The fact that black can fight against white is fascinating, seen from the passage below:

They killed a boss so often and so completely they had to bring him back to life to pulp him one more time. Tasting hot mealcake among pine trees, they beat it away. Singing love songs to Mr. Death, they smashed his head. More than the rest, they killed the flirt whom folks called Life for leading them on. Making them think the next sunrise would be worth it; that another stroke of time would do it at last. (Morrison,1987: 131).

The passage above states that black can do what white do, that is killing. It shows that there is possibility to change the rule and take control in order to make ethnic segregation over, and human equality exists. Black also have strength and courage to fight against white domination and it is a good sign to raise human egalitarian in the world of America.

In addition, they also challenge the stereotype that women are powerless. Women can do nothing except obey the men's rules. Although black women are being wife and mother, they can stand for themselves. They can survive without men, seen from the quotation below:

Sethe started to turn over on her stomach but changed her mind. She did not want to call Paul D's attention back to her, so she settled for crossing her ankles. (Morrison, 1987; 24)

It happens when Sethe is doubt whether to call Paul D's attention back to her or not, and she decides not to do so. It proves that women can decide things by themselves and stand for their right, even when she needs him. She prefers to settle. It shows that the differentiation due to gender role can be challenged if they are willing to fight against the rules. Men are true leaders, either in society or family, but women also have important role. They can survive without men, they can do multitasking jobs that men think it's trivial things to do.

Women are also able to control over the others through emotion, and make them do as what she told, seen in the passage bellow:

"Where'd you learn to dance?" Denver asked her.

"Nowhere. Look at me do this." Beloved put her fists on her hipsand commenced to skip on bare feet. Denver laughed.

"Now you. Come on," said Beloved.

"You may as well just comeon." Her black skirt swayed from side to side. (Morrison, 1987;74)

Beloved is telling Denver to do what she told, and Denver follows it immediately. Beloved can be seen as the dominance here. Since in Beloved (Morrison, 1987) it is clearly told that Denver actually is stranger which happen to live together with Beloved and following every Beloved's order. It shows that women also have control towards men.

Another proof is that women can also express their opinion and debate for conveying the arguments with the men (Morrison, 1987; 15). That is not a sin to refuse an argument since everybody has choice. Men have choice, so do women. Women can do everything they want, shown in the passage bellow:

"No man? You here by yourself?"

"Me and Denver," she said.

"That all right by you?"

"That's all right by me."

She saw his skepticism and went on. "I cook at a restaurant in town. And I sew a little on the sly." (Morrison, 1987; 10).

The statement above is closely related to the idea of becoming free as well. Morrison tries to show that women can do whatever as well just liked men, especially for black women, since black women suffer the difficulty more as becoming American. She tries to show that men and women also can have the same role. 
Besides, there is humanity service that is being crucial issue faced by black in living as Afro-American. In fact, they cannot get same facility and service like what people get. For example, when they get sick, they cannot enter a hospital to get proper treatment (Morrison, 1987; 3). Doctors are facility for white only, not for black. They are refused because of ethnic segregation. As a result, they can only be treated at home. Eventually, they are dead because they have no proper medicine and treatment. They just have burial near home without any funeral treatment. It shows that humanity service is also differred due to the segregation.

However, Sethe as the main character of the story tries to change the condition by struggling for her child to get treatment in hospital through the doctor. When she wants to bury Beloved, she makes a funeral for her, stated in the passage below:

She had not thought to ask him and it bothered her still that it might have been possible - that for twenty minutes, a half hour, say, she could have had the whole thing, every word she heard the preacher say at the funeral (and all there was to say, surely) engraved on her baby's headstone: Dearly Beloved. But what she got, settled for, was the one word that mattered. She thought it would be enough, rutting among the headstones with the engraver, his young son looking on, the anger in his face so old; the appetite in it quite new. That should certainly be enough. Enough to answer one more preacher, one more abolitionist and a town full of disgust. (Morrison, 1987; 5).

According to the passage above, she wants to show that black also can get service like what people have, such as funeral facility. She believes that everyone is equal despite of ethnic segregation. In the end, she can have funeral for her Beloved, not a burial like what black society have for long time.

After all, Morrison gives message through the story of Beloved that people need to fight back by challenging the idea of differentiation. People are created equally so we have to live in harmony as people supposed to as human being.

\section{CONCLUSION}

It can be concluded that dilemma experienced by the main character is correlated to the ethnic segregation by White Americans against Afro-American by challenging the differentiation into equality, from control, gender role, to humanity service. Black do not have control because they are oppressed by the white's rules. They are powerless to fight against the condition. In terms of gender role, men are powerful over women. They can dominate because they are head of family, and women should obey every men's rule and order. They should watch how they behave in society. in addition, the differentiation of humanity service are also experienced through the treatment for sick and dead people.

Second conclusion is that dilemma exeprienced by the main character is correlated with the ethnic segregation by white Americans against Afro-Americans. Black can challenge the difficulties by struggling for their rights to have equality, either in control, gender role, or humanity service. They can take control over white by some surprising actions such as killing. Women also can have similar role to men such as expressing opinion and debate, not only serving the husband and bearing the children. When they get sick, they can have treatment in hospital and have funeral instead of burial.

The conclusions above shows that Beloved conveys that ethnic segregation can be removed if they understand and accept each other. They can live in harmony without any differentiation or segregration.

\section{REFERENCES}

Guerin, Wilfred. (1999). A Handbook of Critical Approaches to Literature: Fifth Edition. New York: Oxford University.

Morrison, Toni. (1987). Beloved. New York: Vintage International (Random House Inc).

Panda, Srikumari and Sethi, Khagendra. (2017). "Toni Morrison's Beloved and the Bluest Eye: A Saga

ISSN : 2252-6323 
Rainbow: Journal of Literature, Linguistics and Cultural Studies, Vol. 8 (2) (2019)

of Untold Suffering." Journal of Business Management \& Social Sciences Research. 6(10): 101-105.

Rosyidi, Mohamad Ikhwan. (2015). "Bittersweet Cultural Acceptance as a Representation of Skin Colour Differentiation in Toni Morrison's Short Story Sweetness". The 4th ELTLT Conference Proceedings: 446-455.

Sahoo, D. S. (2014, August). A Discourse on Deconstruction. Journal of Research in Humanities and Social Scince, 2(8), 33-35. 